\title{
OPEN The impact of regular sperm donation on bulls' seminal plasma hormonal profile and phantom response
}

\author{
Alicja Kowalczyk ${ }^{1 凶}$, Elżbieta Gałęska ${ }^{1}$, Ewa Czerniawska-Piątkowska² ${ }^{2}$ Anna Szul ${ }^{3}$ \& \\ Leszek Hebda ${ }^{3}$
}

The aim of this study was to analyze the relationship between the concentration of hormones in the seminal plasma, the bull maintenance system in the insemination station, and the regularity of sperm donation and the response to the phantom (libido level). An additional goal was to determine whether there is a relationship between the hormonal profile in the blood, the sperm plasma, the oxidative and antioxidant profile in the blood of bulls and the biometry of their testicles and scrotum, as well as the quality of their sperm in both different seasons and intensities of reproductive use. For the study, 220 healthy and sexually mature Polish Holstein-Friesian bulls were used. They all had normal libido and were fed equally. The animals were grouped according to the scheme: young $(16-20 \mathrm{month} / \mathrm{n}=60)$ and old (26-30 month/n=60) including: individually housed $(n=30)$ and group housed $(n=30)$ young, old individually housed $(n=30)$ and group housed $(n=30)$ ( $n$ total animals $=120)$; young animals donating semen once a week (every Thursday) $(n=25)$ and sporadically (once every two months on a random day of the week) $(n=25)$, old animals donating semen once a week (every Thursday) $(n=25)$ and sporadic donors (once every two months on a random day of the week) $(n=25)(n$ total animals $=100$ ). When analyzing the results of this study, it should be stated that regular use has a positive effect on the secretion of sex hormones in bulls. Higher levels of testosterone and lower levels of estradiol and prostaglandins resulted in higher sexual performance, expressed by a stronger response to the phantom. The differences in favor of regular use were independent of the bull's age. The results of our research illustrate that the quality of semen and its freezing potential may depend on the season and frequency of its collection, as well as on the age of the males.

Insemination stations are losing income every day due to the growing number of males showing problems with sperm donation due to poor libido. Lack of semen means that the station will not produce insemination straws, and a bull showing symptoms of libido disorders is directed to slaughter, which generates even greater losses for the station. It has been observed that almost one quarter of breeding bulls maintained at bull stations are affected by poor libido ${ }^{1}$. The rush to introduce very young individuals into the production system occurred along with the dynamic development of the 'genomic era', which undoubtedly contributed to even greater problems with sexual immaturity in these animals. Moreover, there is a significant loss of time and an increased risk taken by technical personnel to stimulate bulls with a lower libido. Moreover, in such cases a much higher labor input is observed $^{2}$. In the work of Bryant ${ }^{3}$ it was noted that libido is a response to endogenous or exogenous stimuli. This response may be mediated by various physiological mechanisms, male motivation and the experience acquired by the bulls. This parameter can be used to measure the reproductive competences of bulls ${ }^{4}$. This parameter is defined as the time elapsed from exposure to stimuli to the first service, and is calculated using the reaction time ${ }^{5}$. Ejaculation efficiency and semen quality are modified by the level of sexual arousal and performance ${ }^{6-8}$. High sex drive in bulls leads to better erection, penile protrusion, ejaculation thrust, libido, and female mating ability ${ }^{9}$.

Testosterone is the major androgen necessary for spermatogenesis in the testes and is mainly responsible for the maintenance of secondary sexual characteristics and libido and thus promotes sperm production in

${ }^{1}$ Department of Environment Hygiene and Animal Welfare, Wrocław University of Environmental and Life Sciences, Chełmońskiego 38C, 50-576 Wrocław, Poland. 'Department of Ruminant Science, West Pomeranian University of Technology, ul. Klemensa Janickiego 29, 71-270 Szczecin, Poland. ${ }^{3}$ Malopolska Biotechnic Centre Ltd, Krasne, Poland. ${ }^{\square}$ email: alicja.kowalczyk@upwr.edu.pl 
bulls $^{10}$. Luteinizing hormone (LH) and follicle stimulating hormone (FSH) hormones are also responsible for male fertility. These hormones have the ability to modulate testosterone synthesis in Leydig cells. The pituitaryhypothalamus-gonadal axis regulates the secretion of $\mathrm{GnRH}$, which is responsible for the secretion of gonadotrophins and testosterone needed for spermatogenesis, sperm maturation and reproductive behavior. In addition, adiponectin, which is a pleiotryopic regulator of many biological functions, may increase testosterone production, which contributes to an increase in libido. Adiponectin plays an important role in the structure and function of sperm and may also be involved in the fusion of the sperm with the oocyte ${ }^{11}$. Estrogen is the end product of the irreversible transformation of androgens by the aromatase enzyme. Although the influence of seasonality on sperm characteristics and male libido has been extensively studied in various breeds ${ }^{12-15}$, there are no reports on the influence of the intensity of reproductive use of bulls kept in insemination stations on their libido level and the concentration of hormones in the semen plasma. In many studies, the relationship between testosterone in the seminal plasma and sperm quality and sperm motility has not been proven ${ }^{16,17}$. However, there is contradictory information on fertility and testorerone levels in bulls ${ }^{16,17}$. Jeved et al. ${ }^{18}$ found a relationship between higher concetrations of testosterone in semen plasma and bull semen quality including parameters such as $\mathrm{pH}$, motility and sperm count. Moreover, in the case of low libido in bulls, it has been suggested that this is due to low testosterone levels ${ }^{16,17}$.

This study aimed to analyze the relationship between the concentration of hormones in the semen plasma, the bull maintenance system in the insemination station, and the regularity of sperm donation and the response to the phantom (libido level). An additional goal was to determine whether there is a relationship between the hormonal profile in the blood, in sperm plasma, oxidative and antioxidant profile in the blood of bulls and the biometry of their testicles and scrotum, as well as the quality of their sperm in different seasons and different intensities of reproductive use.

\section{Materials and methods}

Animals. The experiment was performed as part of routine activities during the current semen production in the reproductive station and did not require the approval of the ethics committee. These experiments were performed in the Breeding and Insemination Centre 'MCB' (Krasne, Poland).

For the study, 220 healthy, sexually mature and equally-fed Polish Holstein-Friesian bulls with normal libido were used. The animals were grouped according to the scheme: young $(16-20 \mathrm{months} / \mathrm{n}=60)$, old (26-30 months/ $\mathrm{n}=60)$; including: individually housed $(\mathrm{n}=30)$ and group housed $(\mathrm{n}=30)$ young, old individually housed $(n=30)$ and group housed $(n=30)(n$ total animals $=120)$; young animals donating semen once a week (every Thursday) $(n=25)$ and sporadically (once every two months on a random day of the week) $(n=25)$, old animals donating semen once a week (every Thursday) $(n=25)$ and sporadic donors (once every two months on a random day of the week) $(n=25)(n$ total animals $=100)$. The trial was conducted in two phases over summer (May-Oct), and winter (Nov-April) season. The entire experience was conducted over 2 years.

Semen collection and hormone concentration analysis. Two ejaculates were collected from each bull at 7 a.m. using an artificial vagina and the standard phantom intended for cattle. The ejaculates were then centrifuged to separate seminal plasma from sperm cells and the supernatant was used for the hormonal assay. Commercial ELISA kits were used to evaluate the endocrine profile of seminal plasma. The analyzes were performed according to the manufacturer's instructions. Testosterone was determined in seminal plasma of crossbred cattle bulls by Bovine Testosterone (T) ELISA Kit (Cusabio Technology, LLC, USA). The estrogen was detected using a Bovine Estradiol ELISA kit (Cusabio Technology, LLC, USA). Prostaglandin E2 was determined using Prostaglandin E2 ELISA kit (My Biosource, USA).

Assessment of the reaction to the phantom. To assess the reaction to the phantom, a two-point scale was adopted depending on the speed of crossing the yellow line applied to the floor at a distance of $1.5 \mathrm{~m}$ from the phantom; low libido $>3 \mathrm{~s}$, high libido $<2.9 \mathrm{~s}$. Only jumps on the phantom after crossing the indicated line by the bull ended with ejaculation were considered correct. Before starting the timing, each male has the opportunity to sniff the phantom and mount it for the same amount of time ('warm-up exercise').

Blood collection and assessment of hormone profiles. Blood samples were collected by puncture of the jugular vein into heparin tubes (20 IU heparin per $\mathrm{ml}$ of blood) at four-week intervals at various times of the year. Blood samples were collected on the same day and at the same time from all animals.

Blood samples were centrifuged at $1200 \mathrm{~g}$ for $15 \mathrm{~min}$ at $4{ }^{\circ} \mathrm{C}$. Serum samples were separated, removed by pipette, labeled and stored at $-20^{\circ} \mathrm{C}$ in a freezer until further analysis.

Hormonal profile. Serum LH and FSH concentrations were determined by the dual antibody RIA method, while testosterone and estriadol concentrations were determined by the solid-phase RIA method as previously described by Dance et al. ${ }^{19}$ and Moura et al. ${ }^{20}$.

Antioxidant profile. The antioxidant status of the bulls' serum was determined by the analysis of reduced glutathione (GSH), urid acid (UA), total protein (TP) and albumin (ALB). The obtained values of the abovementioned parameters were expressed per liter of blood ${ }^{21}$. 
Oxidation profile. The intensity of the oxidative damage to the proteins was established by determining the concentration of the protein carbonyl content (PCC) and for the intensity of the oxidative stress was analysed blood serum lipid peroxidation assessment (TBARS values).

The concentration of lipid peroxides was determined spectrophotometrically by measuring the concentration of malondialdehyde and other reactive products of thiobarbituric acid resulting from free radical peroxidation of unsaturated fatty acids at high temperature and low $\mathrm{pH}$.

PCC content was determined spectrophotometrically using 2,4 dinitrophenyl hydrazine (DNPH) according to the method of Levine et al. ${ }^{22}$. An extinction coefficient of $21.0 \mathrm{~m}^{-1} \mathrm{~cm}^{-1}$ was used to calculate the carbonyl content per gram of protein.

Quality profiles of semen production. The volume of the ejaculate was measured by reading the graduated tube and the concentration was calculated spectrophotometrically.

The fresh undiluted semen was then evaluated microscopically (Nikon E 200, China) for mass motility. Subsequently, the semen was extended with animal protein-free commercial BIOXcell ${ }^{\circledR}$ extender (IMV Technologies, Laigle, France) to a final concentration of $120 \times 106$ spermatozoa $/ \mathrm{mL}$ and rated in terms of motile sperm percentage, progressive motility and viability. Semen was automatically packed (Bloc Machine FIN, IS 4, France) into polyvinyl chloride (PVC) straws $(0.25 \mathrm{~mL})$ (Biovet, France) which were filled and equilibrated for $1.5 \mathrm{~h}$ at $4{ }^{\circ} \mathrm{C}$. After equilibration, the straws were frozen in liquid nitrogen vapor using a computer controlled automatic freezer from 4 to $-15^{\circ} \mathrm{C}$ at the rate of $-3{ }^{\circ} \mathrm{C} / \mathrm{min}$ and from -15 to $-80^{\circ} \mathrm{C}$ at the rate of $-10^{\circ} \mathrm{C} / \mathrm{min}$ (IMV Technologies, France) ${ }^{23}$.

After reaching $-80^{\circ} \mathrm{C}$, semen straws were plunged into liquid nitrogen and packaged in plastic goblets for $24 \mathrm{~h}$ of storage in the liquid nitrogen container. The straws were thawed in a water bath at $38^{\circ} \mathrm{C}$ for $20 \mathrm{~s}$ and were then examined to evaluate the quality after thawing.

Motility assessment. Mass motility was examined in $20 \mu \mathrm{L}$ of semen which was placed on a prewarmed slide without any cover slip and analyzed under microscope (Nikon E 200, China) equipped with phase-contrast optics $(100 \times)^{24}$. The mass motility was scored into four scales: + no motion, ++ free spermatozoa moving without forming any waves, +++ vigorous movement with moderately rapid waves, ++++ very rapidly moving waves ${ }^{23}$.

Total sperm motility and progressive movement were examined using a Sperm Class Analyzer (SCA, version 5.1, Microptic, Barcelona, Spain), a light microscope (Nikon Eclipse E200). Just prior to analysis, semen was diluted $1: 10$ in a warm $\left(25^{\circ} \mathrm{C}\right)$ physiological solution (sodium chlorate $0.9 \%$ ). Then, $2 \mu \mathrm{L}$ of the prepared sample was placed in a Leja 4 analysis chamber (Leja Products B.V., Holland) at a thickness of $20.0 \mu \mathrm{m}$. The slide was placed on a stage warmer $\left(38^{\circ} \mathrm{C}\right)$. A minimum of 500 cells were evaluated, and depending on sperm concentration, five analyses were performed per sample ${ }^{23}$.

Viability. The double stain SYBR-14 with propidium iodide (L-7011 LIVE/DEAD Sperm Viability Kit; Invitrogen, Molecular Probes, Barcelona, Spain) using flow cytometer was applied (CytoFlex Beckman Coulter, B3-R1-V0, China). For this purpose, $50 \mu \mathrm{L}$ of thawed semen was measured $\left(37^{\circ} \mathrm{C}\right.$ for $20 \mathrm{~s}$ ) and $940 \mu \mathrm{L} \mathrm{NaCl}$ $(0.9 \%)$ and $5 \mu \mathrm{L}$ SYBR 14 were added. The whole was thoroughly mixed and then incubated $\left(36^{\circ} \mathrm{C}\right.$ for $\left.10 \mathrm{~min}\right)$ without light access. Subsequently, $5 \mu \mathrm{L}$ of PI was remixed and incubated for $3 \mathrm{~min}$ without light, followed by a test $^{23}$.

Testicular and scrotal biometrics. Testicular volume was estimated according to the method described by Love et al. ${ }^{24}$ by using the following formula for volume of an ellipsoid, i.e., $4 / 3 \pi \mathrm{abc}$, where, $c=$ length/2, $\mathrm{a}=$ thickness $/ 2$ and $\mathrm{b}=$ width $/ 2$.

Scrotal circumference was estimated with the method explained by the Society of Theriogenology ${ }^{25}$. The scrotum was measured with a caliper and a tape measure. The circumference of the scrotum was measured at its widest point with a taut measuring tape.

Climatic variation. The biometeorological factors, relative ambient temperature and relative humidity values were received from the meteorology station Institute of Meteorology and Water Management. Airport Meteorological Station, located at close proximity of the experimental station for estimation of temperature humidity index (THI) (Table 1).

Statistical analysis. Using the analysis of variance with the LSD test, the influence of such factors as bull's age, housing system, semen collection season, and frequency of collection on the concentration of hormones in the semen plasma were determined. Correlations were calculated between the frequency of sperm collecting and the strength of response to the phantom. Spearman correlations were calculated using the Corr SAS Enterprise Guide procedure. The significance of differences between the means was estimated using the T-test and Fisher's NIR (Least Significant Difference) test. Pearson's correlations were estimated for pairs of the analyzed random variables using the CORR Sas Enterprise Guide procedure (SAS/STAT 9.4, 2013).

Statistical model.

$Y_{i j k l m}=\mu+s_{i}+w b_{j}+s b_{k}+e j_{1}+e_{i j k l m}$.

$\mathrm{Y}_{\mathrm{ijklm}}$-analyzed feature.

$\mu$-expected value of the feature. 


\begin{tabular}{|l|l|l|l|l|c|}
\hline Seasons & Sunshine hours $(\mathbf{h})$ & $\begin{array}{l}\text { Maximum rainfall } \\
(\mathbf{m m})\end{array}$ & $\begin{array}{l}\text { Maximum temperature } \\
\left({ }^{\circ} \mathbf{C}\right)\end{array}$ & $\begin{array}{l}\text { Minimum temperature } \\
\left({ }^{\circ} \mathbf{C}\right)\end{array}$ & Relative humidity $(\%)$ \\
\hline Winter & $2.34 \pm 0.61$ & $11.67 \pm 9.75$ & $2.68 \pm 3.38$ & $-1.98 \pm 2.76$ & $83 \pm 5.73$ \\
\hline Spring & $6.24 \pm 1.15$ & $13.17 \pm 8.18$ & $15.38 \pm 6.76$ & $4.77 \pm 5.29$ & $71.42 \pm 5.29$ \\
\hline Summer & $8.38 \pm 0.51$ & $24.00 \pm 7.77$ & $26.02 \pm 1.16$ & $14.4 \pm 0.96$ & $73.5 \pm 4.71$ \\
\hline Autumn & $4.59 \pm 1.46$ & $10.17 \pm 5.08$ & $15.60 \pm 5.68$ & $6.22 \pm 3.31$ & $82.75 \pm 3.86$ \\
\hline
\end{tabular}

Table 1. Climatological data during the experimental period in the area where the bulls were kept (mean \pm SD). The biometeorological factors, relative ambient temperature and relative humidity values were received from the meteorology station Institute of Meteorology and Water Management. Airport Meteorological Station, located at close proximity of the experimental station for estimation of temperature humidity index (THI).

\begin{tabular}{|c|c|c|c|c|c|c|c|c|c|}
\hline \multirow[b]{2}{*}{$\begin{array}{l}\text { Hormone } \\
\text { profiles }\end{array}$} & \multirow[b]{2}{*}{ Age groups } & \multicolumn{4}{|l|}{ Winter season } & \multicolumn{4}{|c|}{ Summer season } \\
\hline & & \begin{tabular}{|l} 
Regular \\
mean \pm SD
\end{tabular} & LSD young/old & $\begin{array}{l}\text { Irregular } \\
\text { mean } \pm \text { SD }\end{array}$ & LSD young/old & $\begin{array}{l}\text { Regular } \\
\text { mean } \pm \text { SD }\end{array}$ & LSD young/old & $\begin{array}{l}\text { Irregular } \\
\text { ean } \pm \text { SD }\end{array}$ & LSD young/old \\
\hline \multirow{2}{*}{$\begin{array}{l}\text { Testosterone ng/ } \\
\mathrm{mL} \text { ) }\end{array}$} & Young & $8.98^{\mathrm{A}} \pm 0.71$ & * & $8.02^{\mathrm{B}} \pm 0.99$ & d & $8.98^{\mathrm{A}} \pm 0.99$ & & $8.1^{\mathrm{B}} \pm 0.93$ & * \\
\hline & Old & $9.64^{\mathrm{A}} \pm 0.98$ & * & $8.21^{\mathrm{B}} \pm 0.78$ & $\mathrm{f}$ & $8.89^{\mathrm{A}} \pm 1.05$ & & $7.52^{\mathrm{B}} \pm 1.01$ & * \\
\hline \multirow{2}{*}{ Estradiol $\mathrm{pg} / \mathrm{mL}$ ) } & Young & $301.6^{\mathrm{a}} \pm 10.33$ & * & $317.3^{\mathrm{a}} \pm 14.65$ & $\mathrm{a}$ & $351.1^{\mathrm{a}} \pm 17.08$ & * & $374.8^{\mathrm{a}} \pm 17.62$ & * \\
\hline & Old & $322.4^{\mathrm{a}} \pm 15.15$ & * & $350.7^{\mathrm{b}} \pm 16.78$ & $\mathrm{~b}$ & $336.5^{\mathrm{a}} \pm 15.41$ & * & $361.4^{\mathrm{a}} \pm 14.9$ & * \\
\hline \multirow{2}{*}{$\begin{array}{l}\text { Prostaglandin } \mathrm{E}_{2} \\
\mathrm{pg} / \mathrm{mL})\end{array}$} & Young & $21.0^{\mathrm{a}} \pm 0.8$ & & $19.79^{\mathrm{b}} \pm 0.79$ & & $24.8^{\mathrm{a}} \pm 1.07$ & & $24.24^{\mathrm{a}} \pm 1.1$ & \\
\hline & Old & $22.0^{\mathrm{a}} \pm 0.99$ & & $20.2^{\mathrm{b}} \pm 0.83$ & & $23.82^{\mathrm{a}} \pm 0.93$ & & $23.06^{\mathrm{a}} \pm 0.91$ & \\
\hline
\end{tabular}

Table 2. Testosterone, estriadol and prostaglandin concentrations depending on the season and age of the male subjects (mean $\pm \mathrm{SD}$ ). Explanation: different letters in the same lines differ significantly; $\mathrm{a}, \mathrm{b}(P<0.05), \mathrm{A}$, $\mathrm{B}(P<0.01) ;{ }^{\star} P<0.05 ;{ }^{\star} P<0.01 ; L S D$ least significant difference.

$\mathrm{s}_{\mathrm{i}}$-season of sperm collecting $\mathrm{i}=1,2$

$\mathrm{wb}_{\mathrm{j}}$ - bull age class, $\mathrm{j}=1,2$

$\mathrm{sb}_{\mathrm{k}}$-housing system, $\mathrm{k}=1,2$

$\mathrm{ej}_{1}$-frequency of sperm collecting $-\mathrm{l}=\mathrm{reg}$, unreg.

$\mathrm{e}_{\mathrm{ijklm}}$-random error effect.

\section{Results}

Table 2 shows the concentration of testosterone, estradiol, and prostaglandins depending on the season, age of the studied individuals, and regularity of their use.

There was a negative and statistically significant correlation $(r=-0.32)$ between the concentration of testosterone and estradiol in the bulls' seminal plasma. The correlation coefficient between the concentration of testosterone and prostaglandins was 0.11 , while the correlation between the concentration of estradiol and prostaglandins was negative but statistically insignificant $(\mathrm{r}=-0.12)$. Pearson's correlation coefficients were calculated without division by the summer/winter production season. Highly significant differences $(P<0.01)$ were found in the testosterone concentration in the bulls' seminal plasma used regularly and irregularly. These differences were highly significant $(P<0.01)$ regardless of the age of the bulls and the season of their use. This dependence is explained by a higher concentration of testosterone, and thus a higher libido, in substances used regularly. Considering the winter season-among the bulls used regularly, older animals showed a statistically higher concentration of testosterone $(9.64 \mathrm{ng} / \mathrm{mL})$ compared to younger animals $(8.98 \mathrm{ng} / \mathrm{mL})(\mathrm{C}-\mathrm{D})$. Among the bulls used regularly, a significantly higher concentration of testosterone was also noted in older animals (8.21 ng/ $\mathrm{mL})$ compared to in younger siblings $(8.02 \mathrm{ng} / \mathrm{mL})$, the difference turned out to be statistically significant $(\mathrm{e}-\mathrm{f})$. Statistically, in the winter season a significantly higher testosterone concentration was observed in younger bulls, not used regularly $(8.1 \mathrm{ng} / \mathrm{mL})$ compared to the concentration of this hormone in older animals $(7.52 \mathrm{ng} / \mathrm{mL})$. In the winter season, the concentration of estradiol in the seminal plasma of bulls used regularly was lower than in bulls used in the irregular cycle, while for older bulls the concentration was statistically significantly higher $(350.7 \mathrm{pg} / \mathrm{mL})$ compared with irregularly used bulls $(322.4 \mathrm{pg} / \mathrm{mL})$. Comparing the age groups in terms of estradiol concentration, statistically significant differences were found between the estradiol concentration in the groups used regularly and in a variable manner. In the summer season, the concentration of estradiol was higher in bulls used irregularly and in younger animals, but these differences were statistically insignificant. Statistically, a significantly higher concentration of prostaglandins was recorded in the winter season in older animals that were used regularly. In the summer season, the concentration of prostaglandins was statistically higher in the seminal plasma of younger animals than in older animals, regardless of the regularity of sperm collection.

When analyzing the behavior of bulls before jumping onto the phantom (Table 3), their reactions were divided into two classes: weak and strong reactions. Bulls showing a weak and strong reaction to the phantom were compared, regardless of the season of use. In bulls used regularly, significantly higher testosterone concentrations 


\begin{tabular}{|c|c|c|c|c|c|c|}
\hline \multirow[b]{3}{*}{ Hormone profiles } & \multicolumn{2}{|l|}{ Weak } & \multicolumn{2}{|l|}{ Strong } & \multirow{2}{*}{\multicolumn{2}{|c|}{ Housing system }} \\
\hline & \multicolumn{2}{|c|}{ Response to the phantom } & \multicolumn{2}{|c|}{ Response to the phantom } & & \\
\hline & $\begin{array}{l}\text { Donating Regular } \\
\text { mean } \pm \mathrm{SD}\end{array}$ & $\begin{array}{l}\text { Donating Irregular } \\
\text { mean } \pm \text { SD }\end{array}$ & $\begin{array}{l}\text { Donating Regular } \\
\text { mean } \pm \text { SD }\end{array}$ & $\begin{array}{l}\text { Donating Irregular } \\
\text { mean } \pm \text { SD }\end{array}$ & Individual mean \pm SD & Group mean \pm SD \\
\hline Testosterone $(\mathrm{ng} / \mathrm{mL})$ & $8.03^{\mathrm{A}} \pm 0.71$ & $7.83^{\mathrm{B}} \pm 0.99$ & $8.98^{\mathrm{A}} \pm 0.99$ & $8.1^{\mathrm{B}} \pm 0.93$ & $8.22^{\mathrm{a}} \pm 1.16$ & $9.55^{\mathrm{b}} \pm 1.29$ \\
\hline LSD weak/strong & $* *$ & ** & $* *$ & $* *$ & & \\
\hline Estradiol $(\mathrm{pg} / \mathrm{mL})$ & $301.6^{\mathrm{a}} \pm 10.33$ & $317.3^{\mathrm{b}} \pm 14.65$ & $351.1^{\mathrm{a}} \pm 17.08$ & $374.8^{\mathrm{b}} \pm 17.62$ & $333.10^{\mathrm{a}} \pm 11.84$ & $349.92^{\mathrm{a}} \pm 13.97$ \\
\hline LSD weak/strong & * & * & * & * & & \\
\hline $\begin{array}{l}\text { Prostaglandin } \mathrm{E}_{2}(\mathrm{pg} / \\
\mathrm{mL})\end{array}$ & $21.0^{\mathrm{a}} \pm 0.8$ & $19.79^{\mathrm{b}} \pm 0.79$ & $24.8^{\mathrm{a}} \pm 1.07$ & $24.24^{\mathrm{a}} \pm 1.1$ & $22.76^{\mathrm{a}} \pm 1.1$ & $21,07^{\mathrm{a}} \pm 1.53$ \\
\hline LSD weak/strong & * & * & * & * & & \\
\hline
\end{tabular}

Table 3. The strength of the response to the phantom depending on the regularity of use and the concentration of hormones in the seminal plasma (mean \pm SD) in connection with relationship between the male housing system and the concentration of hormones in theirseminal plasma (mean $\pm \mathrm{SD})$. Explanation: different letters in the same column differ significantly; a, b $(P<0.05), \mathrm{C}, \mathrm{D}(P<0.01),{ }^{\star} P<0.05 ;{ }^{* *} P<0.01$. \#Only animals that donate re gularly are included.

\begin{tabular}{|c|c|c|c|c|c|c|}
\hline \multirow[b]{2}{*}{ Season } & \multicolumn{2}{|c|}{ PCC $(\mathrm{mmol} / \mathrm{L})$} & \multirow{2}{*}{\begin{tabular}{|l|} 
Test t \\
Y/O \\
\end{tabular}} & \multicolumn{2}{|c|}{ TBARS (mmol/L) } & \multirow{2}{*}{\begin{tabular}{|l|} 
Test t \\
Y/O \\
\end{tabular}} \\
\hline & Young & Old & & Young & Old & \\
\hline Winter & $16.3 \pm 0.5^{\mathrm{a}}$ & $20.2 \pm 0.8^{\mathrm{a}}$ & $* *$ & $1.1 \pm 0.6^{\mathrm{a}}$ & $0.4 \pm 0.1^{\mathrm{b}}$ & * \\
\hline Spring & $17.2 \pm 0.8^{\mathrm{ab}}$ & $19.4 \pm 0.7^{\mathrm{ab}}$ & ** & $1.2 \pm 0.7^{\mathrm{a}}$ & $0.4 \pm 0.1^{\mathrm{b}}$ & * \\
\hline Summer & $12.3 \pm 0.9^{\mathrm{b}}$ & $16.3 \pm 0.4^{\mathrm{b}}$ & $* *$ & $0.5 \pm 0.1^{b}$ & $1.0 \pm 0.5^{\mathrm{a}}$ & ns \\
\hline Autumn & $16.1 \pm 0.4^{\mathrm{ab}}$ & $17.2 \pm 0.3^{\mathrm{ab}}$ & $* *$ & $0.7 \pm 0.2^{\mathrm{ab}}$ & $0.9 \pm 0.3^{\mathrm{ab}}$ & ns \\
\hline $\mathrm{r}$ & PCC & & & & & \\
\hline TBARS & $0.81^{* *}$ & & & & & \\
\hline
\end{tabular}

Table 4. Concentrations of oxidative stress parameters in the blood serum of younger and older bulls in relation to different season (mean $\pm S D$ ). Description: Values with different letters $(a, b)$ differ significantly between rows at $P<0.05$. PCC protein carbonyl content, TBARS thiobarbituric acid reactive substrates. Test T-t-Student's test, ${ }^{* *} P \leq 0.01 ;{ }^{*} P \leq 0.05$.

were noted statistically, both in individuals showing a weaker and strong response to the phantom. The highest concentration of testosterone was recorded in bulls used regularly and with a strong reaction to the phantom ( $9.54 \mathrm{ng} / \mathrm{mL})$, and the lowest in young bulls, used irregularly. Differences between weak and strong phantom responses were related to testosterone concentration, and these relationships were statistically highly significant $\left(\mathrm{C}-\mathrm{D},{ }^{* *}\right)(P<0.01)$. The concentration of estradiol was statistically, significantly higher in the group of bulls with a poor reaction to the phantom, both used regularly and variably.

When the animals donated sperm regularly, males kept in the group pen showed a statistically higher concentration of testosterone in the semen plasma $(9.55 \mathrm{ng} / \mathrm{mL})$ compared to the animals kept individually $(8.22 \mathrm{ng} /$ $\mathrm{mL}$ ). The concentration of estradiol in the plasma of semen of bulls housed regularly (housed in a single pen) $(333.10 \mathrm{pg} / \mathrm{mL})$ was lower than that of bulls housed in a group pen $(349.92 \mathrm{pg} / \mathrm{mL})$. Prostaglandin concentration was higher in bulls kept in a single pen $(22.76 \mathrm{pg} / \mathrm{mL})$ than in bulls kept in a group pen $(21.07 \mathrm{pg} / \mathrm{mL})$.

Statistically significant differences were observed (Table 4) between PCC and TBARS for extreme seasons (winter-summer), with the lowest PCC values $(12.3 \mathrm{mmol} / \mathrm{L}$ and $16.3 \mathrm{mmol} / \mathrm{L})$ recorded in summer and the highest in spring $(17.2 \mathrm{mmol} / \mathrm{L}$ in young bulls). In older bulls, the concentration of PCC reached the highest value in winter $(20.2 \mathrm{mmol} / \mathrm{L})$. Differences between age groups regarding PCC content were statistically, highly significant $(P<0.01)$. Statistically significantly higher $(P<0.01)$ TBARS values were recorded for younger bulls in the spring-winter season $(1.1 \mathrm{mmol} / \mathrm{L}$ and $1.2 \mathrm{mmol} / \mathrm{L})$ compared to the summer season $(0.5 \mathrm{mmol} / \mathrm{L})$. Moreover, in older bulls, it was observed that the concentration of TBARS showed the opposite tendency of changes than in the case of young bulls, as in the winter-spring season it was the lowest $(0.4 \mathrm{mmol} / \mathrm{L})$, while in autumn and winter it increased $(0.9 \mathrm{mmol} / \mathrm{L}$ and $1.0 \mathrm{mmol} / \mathrm{L})$. There were no significant differences between the TBARS content in age groups for the summer-autumn seasons. The correlation between PCC and TBARS was 0.812 and was statistically, highly significant $(P<0.01)$.

Analyzing the concentration of TP (Table 5) in the blood, it was found that it increased with warmer seasons. The difference between older and younger bulls was significant $(P<0.05)$ in the spring-winter seasons, and in the following seasons no significant differences between the age groups were found. In terms of ALB concentration, the results remained at a similar level throughout the study period, reaching the lowest values in winter and spring, respectively (Y: 32.0; O: $34.4 \mathrm{~g} / \mathrm{L}$ and Y: 33.2; O: $37.1 \mathrm{~g} / \mathrm{L}$ ), and the highest in summer and in the fall (Y: 36.1; O: $35.0 \mathrm{~g} / \mathrm{L}$ and $\mathrm{Y}: 34.7 ; \mathrm{O}: 34.5 \mathrm{~g} / \mathrm{L}$ ). The lowest $\mathrm{AU}$ values in both bull age groups were observed in winter (Y: 40.3; O: $55.1 \mathrm{mmol} / \mathrm{L}$ ), and the highest in summer (Y: 52.2; O: $63.6 \mathrm{mmol} / \mathrm{L}$ ), whereby these differences were statistically significant $(P<0.05)$. A higher GSH value in terms of concentration was observed in older bulls 


\begin{tabular}{|c|c|c|c|c|c|c|c|c|c|c|c|c|}
\hline Season & $\begin{array}{l}\text { TP }(\mathrm{g} / \mathrm{L}) \\
\text { Young }\end{array}$ & $\begin{array}{l}\text { TP }(g / L) \\
\text { Old }\end{array}$ & \begin{tabular}{|l|} 
Test \\
Y/O
\end{tabular} & $\begin{array}{l}\text { ALB (g/L) } \\
\text { Young }\end{array}$ & $\begin{array}{l}\text { ALB }(g / L) \\
\text { Old }\end{array}$ & \begin{tabular}{|l|} 
Test \\
Y/O
\end{tabular} & $\begin{array}{l}\text { UA (mmol/L) } \\
\text { Young }\end{array}$ & $\begin{array}{l}\text { UA }(\mathrm{mmol} / \mathrm{L}) \\
\text { Old }\end{array}$ & \begin{tabular}{|l|} 
Test \\
Y/O
\end{tabular} & $\begin{array}{l}\text { GSH }(\mathrm{mmol} / \mathrm{L}) \\
\text { Young }\end{array}$ & $\begin{array}{l}\text { GSH }(\mathrm{mmol} / \mathrm{L}) \\
\text { Old }\end{array}$ & $\begin{array}{l}\text { Test } \\
\text { Y/O }\end{array}$ \\
\hline Winter & $75.1 \pm 3.1^{\mathrm{a}}$ & $81.3 \pm 2.1$ & * & $32.0 \pm 2.2$ & $34.4 \pm 3.3$ & * & $40.3 \pm 3.5^{\mathrm{a}}$ & $55.1 \pm 1.9^{\mathrm{a}}$ & * & $24.4 \pm 0.7$ & $28.0 \pm 0.9$ & * \\
\hline Spring & $79.3 \pm 2.4^{\mathrm{a}}$ & $83.2 \pm 2.4$ & * & $33.2 \pm 2.3$ & $37.1 \pm 3.1$ & * & $44.2 \pm 3.3^{\mathrm{a}}$ & $57.6 \pm 2.1^{\mathrm{a}}$ & * & $26.1 \pm 0.6$ & $28.6 \pm 0.5$ & * \\
\hline Summer & $88.5 \pm 2.2^{\mathrm{b}}$ & $84.3 \pm 2.6$ & Ns & $36.1 \pm 4.2$ & $35.0 \pm 1.6$ & ns & $52.2 \pm 4.1^{\mathrm{b}}$ & $63.6 \pm 4.4^{\mathrm{b}}$ & * & $20.1 \pm 0.4$ & $26.3 \pm 0.2$ & * \\
\hline Autumn & $86.4 \pm 2.1^{\mathrm{b}}$ & $85.1 \pm 3.2$ & Ns & $34.7 \pm 4.0$ & $34.5 \pm 1.7$ & ns & $49.0 \pm 3.9^{b}$ & $61.3 \pm 4.1^{\mathrm{a}}$ & * & $22.2 \pm 0.6$ & $27.1 \pm 0.2$ & * \\
\hline
\end{tabular}

Table 5. Concentration of nonenzymatic antioxidants in the blood serum of younger and older bulls in relation to different season (mean $\pm S D$ ). Explanation: Values with different letters $(a, b)$ differ significantly between rows at $P<0.05$. TP total protein, $A L B$ albumins, $U A$ uric acid, GSH reduced glutathione. Test $-\mathrm{t}-$ Student's test, ${ }^{*} P \leq 0.01 ;{ }^{\star} P \leq 0.05 ;$ ns $=P>0.05$.

\begin{tabular}{|c|c|c|c|c|c|c|c|c|c|c|c|c|}
\hline Season & \begin{tabular}{|l|} 
LH (mIU/ \\
mL) \\
Young
\end{tabular} & $\begin{array}{l}\text { LH (mIU/ } \\
\text { mL) } \\
\text { Old }\end{array}$ & $\begin{array}{l}\text { TEST T } \\
\text { Y/O }\end{array}$ & $\begin{array}{l}\text { FSH (mIU/ } \\
\text { mL) } \\
\text { Young }\end{array}$ & $\begin{array}{l}\text { FSH (mIU/ } \\
\text { mL) } \\
\text { Old }\end{array}$ & $\begin{array}{l}\text { TEST T } \\
\text { Y/O }\end{array}$ & \begin{tabular}{|l|} 
Testosterone \\
$(\mathbf{n g} / \mathrm{mL})$ \\
Young
\end{tabular} & \begin{tabular}{|l|} 
Testosterone \\
$(\mathrm{ng} / \mathrm{mL})$ \\
Old
\end{tabular} & $\begin{array}{l}\text { TEST T } \\
\mathrm{Y} / \mathrm{O}\end{array}$ & $\begin{array}{l}\text { Estradiol } \\
\text { (pg/mL) } \\
\text { Young }\end{array}$ & $\begin{array}{l}\text { Estradiol } \\
(\mathrm{pg} / \mathrm{mL}) \\
\text { Old }\end{array}$ & $\begin{array}{l}\text { TEST T } \\
\text { Y/O }\end{array}$ \\
\hline Winter & $3.5 \pm 1.1^{\mathrm{a}}$ & $3.0 \pm 1.5^{\mathrm{ab}}$ & NS & $26.11 \pm 5.5^{\mathrm{a}}$ & $29.18 \pm 6.6^{\mathrm{a}}$ & NS & $101.55 \pm 1.3^{\mathrm{ab}}$ & $94.55 \pm 1.3^{\mathrm{ab}}$ & ** & $4.4 \pm 0.2^{\mathrm{b}}$ & $5.6 \pm 0.4^{\mathrm{b}}$ & * \\
\hline Spring & $3.16 \pm 1.2^{\mathrm{ab}}$ & $3.10 \pm 2.0^{\mathrm{ab}}$ & NS & $22.0 \pm 7.2^{\mathrm{a}}$ & $25.34 \pm 5.3^{\mathrm{a}}$ & NS & $92.30 \pm 1.1^{\mathrm{ab}}$ & $100.76 \pm 1.1^{\mathrm{a}}$ & ** & $8.2 \pm 0.2^{\mathrm{a}}$ & $10.8 \pm 0.3^{\mathrm{a}}$ & * \\
\hline Summer & $2.66 \pm 1.4^{\mathrm{b}}$ & $3.98 \pm 1.9^{\mathrm{a}}$ & * & $9.04 \pm 3.1^{\mathrm{b}}$ & $14.68 \pm 1.9^{\mathrm{b}}$ & * & $139.24 \pm 1.6^{\mathrm{a}}$ & $156.90 \pm 1.6^{\mathrm{a}}$ & ** & $5.1 \pm 0.5^{\mathrm{ab}}$ & $8.2 \pm 0.4^{\mathrm{ab}}$ & * \\
\hline Autumn & $2.71 \pm 1.2^{\mathrm{b}}$ & $2.87 \pm 1.7^{\mathrm{b}}$ & NS & $13.13 \pm 2.2^{\mathrm{b}}$ & $13.90 \pm 1.7^{\mathrm{b}}$ & NS & $86.07 \pm 1.5^{\mathrm{b}}$ & $44.71 \pm 1.5^{\mathrm{b}}$ & $* *$ & $7.04 \pm 0.7^{\mathrm{ab}}$ & $9.1 \pm 0.6^{\mathrm{a}}$ & * \\
\hline
\end{tabular}

Table 6. Concentration of hormones in the blood serum of younger and older bulls in relation to different season (mean $\pm \mathrm{SD}$ ). Explanation: Values with different letters $(\mathrm{a}, \mathrm{b})$ differ significantly between rows $P<0.05$. Test-t-Student's test, ${ }^{*} P \leq 0.01 ;{ }^{\star} P \leq 0.05 ; \mathrm{ns}=P>0.05$.

compared to young bulls. The lowest concentration of GSH in both examined age groups was observed in summer, and in turn, the highest in spring (Y: 26.1; O: $28.6 \mathrm{mmol} / \mathrm{L}$ ) (Table 6).

Analyzing the concentration of luteinizing hormone (LH), it can be noticed that in the case of young animals these values decreased in the period from winter to summer, then in autumn they increased slightly, while in the case of older animals a reverse trend was observed and the concentration of $\mathrm{LH}$ increased from winter to summer, to then be lowered in the fall. There were no statistically significant differences in the concentrations of luteinizing hormone (LH) between young and old animals in winter, spring and autumn. The values of LH concentrations in summer were significantly different $(P<0.05)$ depending on the age of the animal and amounted to $2.66 \mathrm{mIU} / \mathrm{mL}$ for young bulls and $3.98 \mathrm{mIU} / \mathrm{mL}$ for old bulls, respectively. In the case of old animals, these values were higher. The LH concentration in the summer season, amounting to $2.66 \mathrm{mIU} / \mathrm{mL}$, in young animals was significantly lower $(P<0.05)$ compared to those of all ages in the spring and winter seasons. The lowest concentration of $\mathrm{LH}$ was in the summer season in young animals $(2.66 \mathrm{mIU} / \mathrm{mL})$, while the highest concentration was in old animals in the same period $(3.98 \mathrm{mIU} / \mathrm{mL})$.

When analyzing the values of follicle stimulating hormone (FSH) concentrations, a downward trend can be noticed in the period from winter to autumn, except for young animals in the autumn period, because in their case the concentration increased compared to the previous season, i.e. in summer, and amounted to $13.13 \mathrm{mIU} /$ $\mathrm{mL}$. In any single study period, no significant differences $(P<0.05)$ were observed in the concentration values between animals in terms of their age. The concentration of FSH in spring and winter was significantly higher $(P<0.05)$ in bulls of all ages compared to summer and autumn months and amounted to $26.11 \pm 5.5$ for young bulls and $29.18 \mathrm{mIU} / \mathrm{mL}$ for old specimens in winter. In the spring season concentration of FSH was on level $22.0 \mathrm{mIU} / \mathrm{mL}$ in young males and in old $25.34 \mathrm{mIU} / \mathrm{mL}$. The lowest concentration of FSH was observed in young animals in summer $(09.04 \mathrm{mIU} / \mathrm{mL})$ and the highest in old animals in winter $(29.18 \mathrm{mIU} / \mathrm{mL})$.

Analyzing the testosterone concentration, an upward trend can be noticed in the older animals from winter to summer, followed by a decrease in the described values. There were no statistically significant differences in testosterone concentrations, both in young and old animals, between winter, spring and summer months. A highly significant statistical difference $(P<0.01)$ was demonstrated in the fall in relation to the remaining seasons of the year, while in the autumn months younger bulls had statistically insignificantly higher testosterone levels than old animals. The lowest value of testosterone concentration was observed in old individuals in the fall $(44.71 \mathrm{ng} / \mathrm{mL})$, while the highest value was in old bulls in the summer period $(156.90 \mathrm{ng} / \mathrm{mL})$.

In the case of estradiol levels, the age groups did not significantly differ statistically at specific times of the year. Significant differences $(P<0.05)$ were, however, observed in the winter months, when the estradiol concentration was lower in both age groups compared to the rest of the year. The lowest estradiol concentration was found in winter in young animals and it is equal to $4.4 \mathrm{pg} / \mathrm{mL}$. The highest concentration of estradiol was obtained in the spring months in older animals and was $10.8 \mathrm{pg} / \mathrm{mL}$.

Highly significant $(P<0.01)$ correlations (Table 7$)$ were noted between PCC and TBARS and ALB, as well as between TP and UA. Significant correlations $(P<0.05)$ were found between: PCC and TP, TP and ALB, and ALB and UA. The other correlation coefficients were statistically insignificant. Highly significant $(P<0.01)$ and positive correlations were noted between blood testosterone level and blood LH level (0.36) and between LH and FSH (0.69). Highly significant $(P<0.01)$ but negative correlations were found between blood testosterone 


\begin{tabular}{|l|l|l|l|l|l|l|l|l|l|}
\hline & PCC & TP & ALB & UA & GSH & ALL & Estradiol & FSH & LH \\
\hline TBARS & $0.81^{* *}$ & $0.028 \mathrm{~ns}$ & $0,171 \mathrm{~ns}$ & $0,069 \mathrm{~ns}$ & $0.163 \mathrm{~ns}$ & & & & \\
\hline PCC & - & $0.321^{*}$ & $0.485^{* *}$ & $0.032 \mathrm{~ns}$ & $0.079 \mathrm{~ns}$ & & & & \\
\hline TP & & - & $0.466^{*}$ & $0.512^{* *}$ & $0.139 \mathrm{~ns}$ & & & & \\
\hline ALB & & & - & $0.361^{*}$ & $0.014 \mathrm{~ns}$ & & & & \\
\hline UA & & & & - & $0.144 \mathrm{~ns}$ & & & & \\
\hline Summer & PCC & TP & ALB & UA & GSH & & & & \\
\hline TBARS & $0.72^{* *}$ & $0.048 \mathrm{~ns}$ & $0.179 \mathrm{~ns}$ & $0.069 \mathrm{~ns}$ & $0.163 \mathrm{~ns}$ & & & & \\
\hline PCC & - & $0.465^{*}$ & $0.485^{* *}$ & $0.032 \mathrm{~ns}$ & $0.429 \mathrm{~ns}$ & & & & \\
\hline TP & & - & $0.466^{*}$ & $0.513^{* *}$ & $0.155 \mathrm{~ns}$ & & & & \\
\hline ALB & & & - & $0.362^{*}$ & $0.036 \mathrm{~ns}$ & Testosterone & $-0.41^{* *}$ & $0.11 \mathrm{~ns}$ & $0.36^{* *}$ \\
\hline UA & & & & - & $0.064 \mathrm{~ns}$ & Estriadol & & $-0.25^{* *}$ & $-0.023 \mathrm{~ns}$ \\
\hline winter & PCC & TP & ALB & UA & GSH & FSH & & & $0.69^{* *}$ \\
\hline TBARS & $0.81^{* *}$ & $0.003 \mathrm{~ns}$ & $0,182 \mathrm{~ns}$ & $0,079 \mathrm{~ns}$ & $0.187 \mathrm{~ns}$ & winter & Estradiol & FSH & LH \\
\hline PCC & - & $0.465^{*}$ & $0.485^{* *}$ & $0.036 \mathrm{~ns}$ & $0.041 \mathrm{~ns}$ & Testosterone & $-0.39^{* *}$ & $0.031 \mathrm{~ns}$ & $0.39^{* *}$ \\
\hline TP & & - & $0.466^{*}$ & $0.512^{* *}$ & $0.136 \mathrm{~ns}$ & Estriadol & & $-0.14^{* *}$ & $-0.033 \mathrm{~ns}$ \\
\hline ALB & & & - & $0.361^{*}$ & $0.037 \mathrm{~ns}$ & FSH & & & $0.61^{* *}$ \\
\hline UA & & & & - & $0.146 \mathrm{~ns}$ & summer & Estradiol & FSH & LH \\
\hline & & & & & & Testosterone & $-0.43^{* *}$ & $0.11 \mathrm{~ns}$ & $0.44^{* *}$ \\
\hline & & & & & & Estriadol & & $-0.22^{* *}$ & $-0.096 \mathrm{~ns}$ \\
\hline & & & & & & FSH & & & $0.54^{* *}$ \\
\hline
\end{tabular}

Table 7. Correlations between the season and bulls' blood parameters. Explanation: ${ }^{\star \star} P \leq 0.01 ;{ }^{\star} P \leq 0.05$; $\mathrm{ns}=P>0.05$.

\begin{tabular}{|c|c|c|c|c|c|c|}
\hline \multirow[b]{2}{*}{ Parameters } & \multicolumn{2}{|c|}{ Regular semen donation } & \multirow{2}{*}{\begin{tabular}{|l|} 
LSD \\
$\mathbf{R} / \mathbf{I}$ \\
$\mathbf{Y}$ \\
\end{tabular}} & \multicolumn{2}{|c|}{ Irregular semen donation } & \multirow{2}{*}{\begin{tabular}{|l|} 
LSD \\
R/I \\
O
\end{tabular}} \\
\hline & Young & Old & & Young & Old & \\
\hline Volume $(\mathrm{mL})$ & $4.2 \pm 2.1$ & $6.5 \pm 3.2$ & & $3.9 \pm 2.2$ & $5.7 \pm 3.1$ & \\
\hline Concentration $\left(\times 10^{6} / \mathrm{mm}^{3}\right)$ & $1774 \pm 221.6^{\mathrm{A}}$ & $2831 \pm 604.9^{\mathrm{B}}$ & ** & $1905 \pm 373.62^{\mathrm{A}}$ & $3004 \pm 825.25^{\mathrm{B}}$ & ** \\
\hline Live (\%) & $83.52 \pm 3.70$ & $84.45 \pm 4.53$ & * & $76.83 \pm 3.99$ & $75.97 \pm 5.12$ & * \\
\hline Dead (\%) & $10.03 \pm 1.11$ & $9.90 \pm 1.19$ & * & $11.10 \pm 2.72$ & $11.75 \pm 3.57$ & * \\
\hline Total motility (\%) & $78.28 \pm 5.36$ & $80.02 \pm 5.03$ & * & $73.51 \pm 6.79$ & $75.25 \pm 4.04$ & * \\
\hline Progressive movement (\%) & $46.67 \pm 0.88$ & $51.16 \pm 1.96$ & * & $41.32 \pm 1.23$ & $44.19 \pm 2.91$ & ** \\
\hline Mass motility & ++ & +++ & & ++ & ++ & \\
\hline
\end{tabular}

Table 8. Semen quality parameters of young and old bulls during regular and irregular sperm donation (mean $\pm \mathrm{SD}$ ). Explanation: Values with different letters $(\mathrm{a}, \mathrm{b})$ differ significantly between columns at $P<0.05$, ${ }^{\star} P<0.05 ;{ }^{\star \star} P<0.01$.

content and estradiol content (-0.41) and between estradiol and FSH (-0.25). The correlations between FSH and testosterone in the blood as well as estradiol and LU levels were not statistically significant. The values of the correlation between the content of hormones in the blood and analogous hormones in seminal plasma were highly significant $(P<0.01)$, positive and reached $0.98-0.999$.

Table 8 shows the parameters of semen quality, taking into account age groups (Young-Old) and groups used on a regular and irregular basis. The volume of ejaculate was higher in the group of older $(6.5 \mathrm{~mL})$ and regular used bulls (old $6.5 \mathrm{~mL}$; young $4.2 \mathrm{~mL}$ ), but these differences were not statistically significant. Statistically, sperm concentration was highly significantly $(P<0.01)$ highest in older bulls $(2,831 \times 106 / \mathrm{mm} 3)$ and in bulls from both age groups, but used on a regular basis. The percentage of live sperm was higher in animals donating sperm regularly (in both age groups) by an average of $6.69 \%$ (young) and $8.54 \%$ (old). These differences were statistically, significantly $(P<0.05)$ higher in the group of bulls giving sperm regularly, regardless of the age of the male. The opposite tendency was observed for the percentage of dead sperm-in the group of regularly used there were significantly less $(P<0.05)$ dead sperm than in the group that donated irregularly. There was no significant difference between age groups in this parameter. Regularly used bulls, regardless of age, had better sperm motility results (total motility and progressive movement). Moreover, the semen of older bulls showed better total motility and progressive movement in comparison to younger bulls, regardless of the regularity of semen collection. The mobility of the sperm mass was higher $(+++)$ in older bulls used regularly than in younger males $(++)$. There were no differences in sperm mass motility in bulls used irregularly. 


\begin{tabular}{|c|c|c|c|c|c|}
\hline \multirow[b]{2}{*}{ Parameters } & \multicolumn{2}{|l|}{ Fresh } & \multicolumn{2}{|l|}{ Frozen } & \multirow[b]{2}{*}{ Season } \\
\hline & Young & Old & Young & Old & \\
\hline Volume $(\mathrm{mL})$ & $4.9 \pm 1.2^{\mathrm{b}}$ & $7.1 \pm 2.7^{\mathrm{a}}$ & - & - & \multirow{7}{*}{ Winter } \\
\hline Concentration $\left(\times 10^{6} / \mathrm{mm}^{3}\right)$ & $1646 \pm 254.1^{\mathrm{b}}$ & $2598 \pm 555.76^{\mathrm{a}}$ & - & - & \\
\hline Live (\%) & $79.45 \pm 4.4$ & $84.87 \pm 4.2$ & $53.50 \pm 2.24$ & $59.02 \pm 4.57$ & \\
\hline Dead (\%) & $13.33 \pm 1.08$ & $10.96 \pm 0.97$ & $42.13 \pm 3.12$ & $38.28 \pm 3.99$ & \\
\hline Total motility (\%) & $76.71 \pm 4.89$ & $80.81 \pm 5.05$ & $48.54 \pm 3.65$ & $52.10 \pm 4.06$ & \\
\hline Progressive movement (\%) & $41.30 \pm 2.06$ & $49.93 \pm 5.15$ & $30.30 \pm 1.91$ & $32.71 \pm 2.04$ & \\
\hline Mass motility & +++ & +++ & - & - & \\
\hline Volume $(\mathrm{mL})$ & $3.9 \pm 1.9^{b}$ & $5.1 \pm 3.2^{\mathrm{a}}$ & - & - & \multirow{7}{*}{ Spring } \\
\hline Concentration $\left(\times 10^{6} / \mathrm{mm}^{3}\right)$ & $1247 \pm 431.5^{\mathrm{b}}$ & $2854 \pm 477.65^{\mathrm{a}}$ & - & - & \\
\hline Live (\%) & $72.15 \pm 3.54^{\mathrm{b}}$ & $86.70 \pm 5.1^{\mathrm{a}}$ & $49.59 \pm 2.1^{\mathrm{b}}$ & $57.63 \pm 3.12^{\mathrm{a}}$ & \\
\hline Dead (\%) & $11.44 \pm 2.00$ & $10.11 \pm 1.16$ & $50.08 \pm 2.2^{\mathrm{a}}$ & $40.06 \pm 3.0^{\mathrm{b}}$ & \\
\hline Total motility (\%) & $72.25 \pm 3.93^{\mathrm{b}}$ & $79.64 \pm 5.47^{\mathrm{a}}$ & $44.19 \pm 3.26$ & $49.77 \pm 3.92$ & \\
\hline Progressive movement (\%) & $44.42 \pm 1.54$ & $50.03 \pm 4.98$ & $31.14 \pm 1.99$ & $35.01 \pm 1.96$ & \\
\hline Mass motility & +++ & +++ & - & - & \\
\hline Volume $(\mathrm{mL})$ & $3.8 \pm 1.6^{\mathrm{b}}$ & $5.0 \pm 2.3^{\mathrm{a}}$ & - & - & \multirow{7}{*}{ Summer } \\
\hline Concentration $\left(\times 10^{6} / \mathrm{mm}^{3}\right)$ & $1151 \pm 166.82^{b}$ & $2113 \pm 453.12^{\mathrm{a}}$ & - & - & \\
\hline Live (\%) & $67.29 \pm 3.72$ & $72.15 \pm 3.91$ & $44.05 \pm 5.92^{\mathrm{b}}$ & $54.67 \pm 4.14^{\mathrm{a}}$ & \\
\hline Dead (\%) & $16.17 \pm 1.10$ & $12.21 \pm 1.01$ & $51.99 \pm 4.33$ & $50.50 \pm 5.18$ & \\
\hline Total motility (\%) & $65.33 \pm 3.28$ & $67.90 \pm 3.12$ & $39.86 \pm 3.77$ & $42.94 \pm 3.09$ & \\
\hline Progressive movement (\%) & $36.44 \pm 4.27$ & $39.85 \pm 4.66$ & $28.88 \pm 1.06$ & $32.26 \pm 1.13$ & \\
\hline Mass motility & ++ & ++ & - & - & \\
\hline Volume $(\mathrm{mL})$ & $4.1 \pm 0.8^{\mathrm{b}}$ & $5.2 \pm 2.9^{\mathrm{a}}$ & - & - & \multirow{7}{*}{ Autumn } \\
\hline Concentration $\left(\times 10^{6} / \mathrm{mm}^{3}\right)$ & $1328 \pm 205.68^{b}$ & $2355 \pm 399.91^{\mathrm{a}}$ & - & - & \\
\hline Live (\%) & $70.70 \pm 2.92$ & $75.51 \pm 4.16$ & $46.01 \pm 1.98^{\mathrm{b}}$ & $56.30 \pm 4.10^{\mathrm{a}}$ & \\
\hline Dead (\%) & $13.06 \pm 1.96$ & $12.57 \pm 1.10$ & $44.99 \pm 1.20$ & $42.53 \pm 2.28$ & \\
\hline Total motility (\%) & $69.92 \pm 4.05$ & $73.12 \pm 6.14$ & $40.36 \pm 2.70^{\mathrm{b}}$ & $49.69 \pm 4.44^{\mathrm{a}}$ & \\
\hline Progressive movement (\%) & $37.00 \pm 3.60$ & $41.17 \pm 4.62$ & $30.11 \pm 2.94^{\mathrm{b}}$ & $37.71 \pm 2.73^{\mathrm{a}}$ & \\
\hline Mass motility & ++ & +++ & - & - & \\
\hline
\end{tabular}

Table 9. Quality parameters of fresh and frozen semen of young and old bulls depending on the season $($ mean \pm SD). Description: Values with different letters $(\mathrm{a}, \mathrm{b})$ differ significantly between columns at $P<0.05$

Table 9 presents the values of the traits related to the quality of fresh and frozen semen in bulls from two age groups and divided into seasons. In the winter season, fresh semen obtained from older males had a significantly $(P<0.05)$ higher volume $(7.1 \mathrm{~mL})$ and concentration $\left(2598 \times 10^{6} / \mathrm{mm}^{3}\right)$ compared to young bulls $(4.9 \mathrm{~mL}$ and $\left.1646 \times 10^{6} / \mathrm{mm}^{3}\right)$. In terms of the mobility and viability parameters of fresh and frozen semen, no significant differences were observed during the winter season within the studied age groups. In contrast, in the spring season, both the volume of fresh ejaculate, its concentration and the percentage of live and motile sperm were significantly $(P<0.05)$ higher in the group of older bulls. The frozen semen of the younger bulls was statistically of significantly $(P<0.05)$ lower quality in terms of viability than the older bulls and contained on average $8.04 \%$ less viable sperm than the frozen semen of older males. In the summer season, ejaculate volume and sperm concentration differed significantly between young and old bulls, $1.2 \mathrm{~mL}$ and $962 \times 10^{6} / \mathrm{mm}^{3}$ sperm, respectively. Moreover, in terms of sperm concentration, it was observed that in the summer season this value was the lowest among all analyzed seasons of use. Similarly, in terms of viability and sperm motility, the analyzed ejaculates were of the poorest quality in the summer season. However, in the autumn season, significant differences in terms of sperm mobility and viability were observed between older and younger males by analyzing their frozen semen. Older bulls were characterized by significantly $(P<0.05)$ better parameters of frozen semen than younger males. The highest mobility of sperm mass was observed in the winter and spring seasons.

Table 10 resents the values of the correlation along with their significance between the analyzed hormones, the volume and concentration of sperm, and the temperature on the day of sperm collection.

The testosterone level was negatively correlated with the level of estradiol $(-0.32)$ and positively with prostaglandin (0.11). The level of estradiol was also negatively correlated with the level of prostaglandins in the blood $(-0.12)$. The quoted correlations turned out to be statistically highly significant $(P<0.01)$. In the winter season, negative and highly significant correlations were noted between the levels of estradiol and testosterone $(-0.28)$ and estradiol and prostaglandins (-0.13). A similar tendency was observed in the summer season.

The volume of semen was positively and highly significantly correlated with the level of testosterone. Testosterone was positively and statistically significantly correlated with the value of sperm concentration. There were no significant correlations between the level of estradiol and the volume of semen, while the level of sperm 


\begin{tabular}{|c|c|c|c|c|}
\hline & Estradiol & Prostaglandin & Seminal volune & Concentration \\
\hline \multicolumn{5}{|l|}{ ALL } \\
\hline Testosterone & $-0.32^{\star *}$ & $0.11^{* *}$ & $0.33^{* *}$ & $0.31^{*}$ \\
\hline Estriadol & & $-0.12^{\star \star}$ & 0.04 & $-0.10^{*}$ \\
\hline Prostaglandin & & & $0.12^{*}$ & $0.28^{*}$ \\
\hline \multicolumn{5}{|l|}{ Winter } \\
\hline Testosterone & $-0.28^{\star *}$ & $0.10^{* *}$ & $0.35^{* *}$ & $0.32^{*}$ \\
\hline Estriadol & & $-0.13^{* *}$ & -0.22 & $-0.12^{*}$ \\
\hline Prostaglandin & & & $0.13^{*}$ & $0.27^{*}$ \\
\hline \multicolumn{5}{|l|}{ Summer } \\
\hline Testosterone & $-0.34^{* *}$ & $0.14^{* *}$ & $0.32^{* *}$ & $0.29^{*}$ \\
\hline Estriadol & & $-0.11^{* *}$ & -0.11 & $-0.11^{*}$ \\
\hline Prostaglandin & & & $0.12^{*}$ & $0.26^{*}$ \\
\hline
\end{tabular}

Table 10. Correlations of seminal hormone levels, semen volume and concentration, taking into account the semen collection season. Explanation: ${ }^{\star *} P \leq 0.01 ;{ }^{\star} P \leq 0.05 ; \mathrm{ns}=P>0.05$.

\begin{tabular}{|c|c|c|c|c|c|c|c|c|c|c|}
\hline & Estradiol & Prostaglandin & $\begin{array}{l}\text { Seminal } \\
\text { volume }\end{array}$ & Concentration & $\begin{array}{l}\text { Scrotal } \\
\text { circumference } \\
\text { (cm) }\end{array}$ & $\begin{array}{l}\text { Testicular } \\
\text { volume }\left(\mathrm{cm}^{3)}\right.\end{array}$ & $\begin{array}{l}\text { Total motility } \\
\text { (\%) }\end{array}$ & Dead (\%) & Live (\%) & $\begin{array}{l}\text { Progressive } \\
\text { movement } \\
(\%)\end{array}$ \\
\hline \multicolumn{11}{|l|}{ ALL } \\
\hline Testosterone & $-0.32^{\star *}$ & $0.11^{* *}$ & $0.73^{* *}$ & $0.31^{*}$ & $0.82^{* *}$ & $0.72^{* *}$ & $0.86^{* *}$ & $-0.88^{* *}$ & $0.86^{* *}$ & $0.88^{* *}$ \\
\hline Estradiol & & $-0.12^{* *}$ & 0.04 & $-0.10^{*}$ & $-0.42^{* *}$ & $-0.34^{* *}$ & $-0.21^{*}$ & $0.32^{*}$ & $-0.23^{*}$ & $-0.41^{*}$ \\
\hline Prostaglandin & & & $0.19^{*}$ & $0.28^{*}$ & $0.33^{* *}$ & $0.24^{*}$ & $0.22^{*}$ & $0.12^{*}$ & $0.14^{*}$ & $0.21^{*}$ \\
\hline \multicolumn{11}{|l|}{ Winter } \\
\hline Testosterone & $-0.28^{* *}$ & $0.10^{* *}$ & $0.35^{* *}$ & $0.32^{*}$ & $0.79^{* *}$ & $0.71^{* *}$ & $0.82^{* *}$ & $-0.85^{\star *}$ & $0.82^{* *}$ & $0.84^{* *}$ \\
\hline Estradiol & & $-0.13^{* *}$ & -0.22 & $-0.12^{*}$ & $-0.42^{\star *}$ & $-0.25^{* *}$ & $-0.19^{*}$ & $0.31^{*}$ & $-0.22^{\star}$ & $-0.38^{*}$ \\
\hline Prostaglandin & & & $0.13^{*}$ & $0.27^{*}$ & $0.31^{* *}$ & $0.22^{*}$ & $0.18^{\star}$ & $0.11^{*}$ & $0.13^{*}$ & $0.24^{*}$ \\
\hline \multicolumn{11}{|l|}{ Summer } \\
\hline Testosterone & $-0.34^{* *}$ & $0.14^{* *}$ & $0.32^{\star *}$ & $0.29^{*}$ & $0.84^{* *}$ & $0.73^{* *}$ & $0.88^{* *}$ & $-0.89^{* *}$ & $0.86^{* *}$ & $0.92^{* *}$ \\
\hline Estradiol & & $-0.11^{* *}$ & -0.11 & $-0.11^{*}$ & $-0.42^{\star *}$ & $-0.34^{* *}$ & $-0.21^{*}$ & $0.32^{*}$ & $-0.31^{*}$ & $-0.44^{*}$ \\
\hline Prostaglandin & & & $0.12^{*}$ & $0.26^{*}$ & $0.33^{* *}$ & $0.24^{*}$ & $0.22^{*}$ & $0.11^{*}$ & $0.14^{*}$ & $0.19^{*}$ \\
\hline \multicolumn{11}{|l|}{ Regular } \\
\hline Testosterone & $-0.31^{\star *}$ & $0.15^{* *}$ & $0.42^{* *}$ & $0.39^{*}$ & $0.82^{* *}$ & $0.80^{* *}$ & $0.85^{* *}$ & $-0.86^{* *}$ & $0.83^{* *}$ & $0.85^{* *}$ \\
\hline Estradiol & & $-0.22^{\star *}$ & -0.29 & $-0.31^{*}$ & $-0.53^{* *}$ & $-0.35^{* *}$ & $-0.39^{*}$ & $0.34^{*}$ & $-0.32^{*}$ & $-0.39^{*}$ \\
\hline Prostaglandin & & & $0.14^{*}$ & $0.29^{*}$ & $0.34^{* *}$ & $0.22^{*}$ & $0.21^{*}$ & $0.30^{*}$ & 0.23 & $0.24^{*}$ \\
\hline \multicolumn{11}{|l|}{ Irregular } \\
\hline Testosterone & $-0.31^{\star *}$ & $0.14^{* *}$ & $0.36^{* *}$ & $0.29^{*}$ & $0.84^{* *}$ & $0.73^{* *}$ & $0.88^{* *}$ & $-0.89^{* *}$ & $0.86^{* *}$ & $0.92^{* *}$ \\
\hline Estradiol & & $-0.10^{* *}$ & -0.13 & $-0.11^{*}$ & $-0.42^{\star *}$ & $-0.34^{* *}$ & $-0.21^{*}$ & $0.32^{*}$ & $-0.31^{*}$ & $-0.44^{*}$ \\
\hline Prostaglandin & & & $0.11^{*}$ & $0.26^{*}$ & $0.33^{* *}$ & $0.24^{*}$ & $0.22^{*}$ & $0.11^{*}$ & $0.14^{*}$ & $0.19^{*}$ \\
\hline
\end{tabular}

Table 11. Correlations of hormone levels and semen quality, taking into account the semen collection season. Explanation: ${ }^{*} P \leq 0.01 ;{ }^{\star} P \leq 0.05 ; \mathrm{ns}=P>0.05$.

concentration was positively correlated with the content of prostaglandins, and negatively with the content of estradiol in the blood. The above-mentioned correlations turned out to be statistically significant.

The testosterone level was negatively correlated (Table 11$)$ with the level of estradiol $(-0.32)$ and positively with prostaglandin (0.11). The level of estradiol was also negatively correlated with the level of prostaglandins in the blood $(-0.12)$. The quoted correlations turned out to be statistically highly significant $(P<0.01)$. In the winter season, negative and highly significant correlations were noted between the levels of estradiol and testosterone $(-0.28)$, and estradiol and prostaglandins $(-0.13)$. A similar tendency was observed in the summer season.

The values of the correlation coefficients between the level of hormones and fresh semen quality parameters were determined. The volume of semen was positively and highly significantly correlated with the level of testosterone. Testosterone was positively and statistically significantly correlated with the value of sperm concentration. There were no significant correlations between the level of estradiol and the volume of semen, while the level of sperm concentration was positively correlated with the content of prostaglandins and negatively with the content of estradiol in the blood. The above-mentioned correlations turned out to be statistically significant $(P<0.05)$.

The testosterone level was correlated with the number of live spermatozoa, their motility and progressive movement highly significantly, with $\mathrm{r}$ exceeding 0.86 , and negatively with the number of dead sperm $(-0.88)$. 


\begin{tabular}{|c|c|c|c|c|c|c|}
\hline \multirow[b]{2}{*}{ Parameters } & \multicolumn{2}{|c|}{ Regular semen donation } & \multirow{2}{*}{$\begin{array}{l}\text { LSD } \\
\text { R/I } \\
\text { Young }\end{array}$} & \multicolumn{2}{|c|}{ Irregular semen donation } & \multirow{2}{*}{$\begin{array}{l}\text { LSD } \\
\text { R/I } \\
\text { Old }\end{array}$} \\
\hline & Young & Old & & Young & Old & \\
\hline Scrotal circumference $(\mathrm{cm})$ & $32.38 \pm 1.56$ & $37.95 \pm 1.83$ & & $35.31 \pm 2.01$ & $39.22 \pm 2.77$ & \\
\hline Testicular volume $\left(\mathrm{cm}^{3}\right)$ & $991.05 \pm 30.30^{\mathrm{b}}$ & $1221.62 \pm 38.26^{\mathrm{a}}$ & * & $1114.57 \pm 41.12^{\mathrm{b}}$ & $1678.91 \pm 69.84^{\mathrm{a}}$ & * \\
\hline
\end{tabular}

Table 12. Testicular biometry in young and old bulls during regular and irregular semen donation $($ mean $\pm \mathrm{SD})$. Explanation: Values with different letters $(\mathrm{a}, \mathrm{b})$ differ significantly between columns at $P<0.05$, ${ }^{\star} P<0.05 ;{ }^{*} P<0.01$.

The level of estradiol was negatively correlated with the motility, progressive movement and live spermatozoa, and positively correlated with the level of dead sperm. Positive and statistically significant correlations were found between the analyzed characteristics of sperm quality and prostaglandins.

The testosterone level was highly significantly correlated with the area $(0.82)$ and volume of the testicles (0.72). Similarly, highly significant, albeit negative, correlations were noted for the level of estradiol by area $(-0.42)$ and testicular volume $(-0.34)$. The prostaglandin level was positively correlated with the surface area (0.34) and testicular volume (0.24).

After applying the division according to the semen collection season and regularity, very similar correlation results between the analyzed values were obtained.

In older bulls (Table 12), The circumference of the scrotum was greater by about $4 \mathrm{~cm}$, both in the group of males used regularly and irregularly. The differences in the circumference of the scrotum were statistically insignificant. However, statistically significant $(P<0.05)$ differences in testicular volume were noted. Older bulls that regularly donate semen had a statistically significantly $(P<0.05)$ larger testicle volume by an average of 230.57 $\mathrm{cm}^{3}$ compared to younger males. This tendency was identical in the group of animals used irregularly, where the volume of testes in younger males was lower by an average of $564.34 \mathrm{~cm}^{3}$. Moreover, males used in an irregular manner were characterized by a greater circumference of the scrotum and a larger volume of testicles compared to males donating sperm regularly.

\section{Discussion}

The poor libido of bulls used in insemination stations is the main source of several difficulties related not only to the handling of such animals, their delayed inclusion in the current production of insemination doses, but most of all the generation of great financial losses. This is because bulls whose reproductive use does not bring profit due to their disorders of sexual encounters, are slaughtered ${ }^{1}$.

The determination of hormones, and in particular of reproductive hormones in semen plasma, is an important diagnostic and therapeutic marker of male fertility disorders.

Testosterone plays a key role in the expression of normal sexual patterns in bulls ${ }^{10,18}$, while the testosterone to estradiol ratio is important in their libido ${ }^{26}$. In our study, we found that regular use of bulls was associated with testosterone levels in semen plasma. Males that were used irregularly had a lower level of the hormone than bulls that regularly ejaculated. Moreover, bulls with higher testosterone levels reacted faster, more effectively, and more strongly to the phantom, which in turn allows us to hypothesize that regular sperm donation may improve bulls' libido levels. Furthermore, we showed that the male group maintenance system was associated with higher levels of testosterone in their semen plasma, suggesting that this system promotes the expression of normal sexual patterns. Perhaps the higher level of this hormone is also due to the fact that during the contact of the bull with other animals, it can "train" the climbing reflexes of other males, which helps to maintain a proper level of libido.

We also showed that the concentration of estradiol was subject to seasonal fluctuations and was increasing with the passing of the winter season. Furthermore, the concentration of estradiol in the seminal plasma of bulls used regularly was lower than in bulls used in an irregular cycle. On the other hand, the bull's maintenance system was not related to the level of this hormone in their sperm plasma.

Prostaglandins present in the ejaculated semen acts through its receptors PTGER1 and PTGER3 and modulate sperm motility, capacitation, acrosome reaction, and fertilizing ability of spermatozoa ${ }^{27}$ by mediating an increase in intracellular calcium concentrations ${ }^{28}$. Moreover, increased concentration of this protein may lead to premature capacitation and acrosome reaction interfering with the fertilization process ${ }^{29}$. In this study, it was observed that the concentration of the above hormone in semen plasma was higher in the summer season than in the winter. Moreover, males used regularly were characterized by a higher concentration of this hormone in sperm plasma. There was also no relationship between the strength of the phantom response and the concentration of prostaglandins, similar to estradiol concentration.

We proved that bull age and regularity of their use were related to the biometric features of the testicles and scrotum. Similar results were obtained by Perumal et al. ${ }^{30}$, who reported that both the age of males and the season of sperm collection have an impact on the biometric features of male testes.

Analyzing the levels of hormones in the peripheral blood of bulls, we showed that they change with the season of the year. These data were also confirmed by other researchers in their experiments ${ }^{30,31}$.

Determining antioxidative and oxidative parameters in the serum of bulls may help in establishing the antioxidative and oxidative status of individual animals during different conditions such as season (temperature outside), housing system, regularity of sperm donating etc.

As the results of our research show, the quality of semen and its freezing potential may depend on the season and frequency of its collection, as well as on the age of the males. Balic et al. ${ }^{32}$ have shown that younger bulls 
are more sensitive to elevated ambient temperatures in summer, when increased pro-oxidative processes in semen plasma and sperm cause a decrease in sperm motility and, consequently, worsen sperm quality. Other researchers ${ }^{33,34}$ report that younger specimens achieve poorer sperm quality parameters than older ones, and that the season of the year significantly affects sperm mobility and viability. The results obtained by us also indicate that the older bulls had both a higher concentration of sperm in the fresh ejaculate, a greater volume of semen and a better viability and mobility (especially after freezing) compared to the young bulls.

Žaja et al. ${ }^{35}$ showed that bulls show high sensitivity to changes in climatic conditions in terms of the analyzed antioxidant and oxidation profile in the blood, which is also confirmed by the results of similar variability in the analyzed profiles.

\section{Conclusion}

The conducted research shows that regular use has a positive effect on the secretion of sex hormones in bulls. Higher levels of testosterone and lower levels of estradiol and prostaglandins resulted in higher sexual performance, expressed by a stronger response to the phantom. The differences in favor of regular use were independent of the bull's age. As the results of our research show, the quality of semen and its freezing potential may depend on the season and frequency of its collection, as well as on the age of the males.

\section{Data availability}

The data underlying this article will be shared on reasonable request to the corresponding author.

Received: 6 February 2021; Accepted: 13 May 2021

Published online: 27 May 2021

\section{References}

1. Kumar, A., Singh, J., Dhaliwal, G. S. \& Singh, P. Incidence and factors associated with poor libido in breeding buffalo bulls. Indian J. Anim. Sci. 78, 143-145 (2008).

2. Le Danvic, C. et al. Enhancing bull sexual behavior using estrus-specific molecules identified in cow urine. Theriogenology 83, 1381-1388 (2015).

3. Bryant, D. G. The ecological basis of behavior. Appl. Anim. Behav. Sci. 22, 215-224 (1989).

4. Ahmad, M., Asmat, M. T. \& Rehman, N. R. Relationship of testicular size and libido to age and season in Sahiwal bulls. Pak. Vet. J. 25, 67-70 (2005).

5. Ott, R. S. \& Memon, M. A. Breeding soundness examinations of rams and bucks. A review. Theriogenology 13, 155-160 (1980).

6. Kondracki, S., Iwanina, M., Wysokinska, A. \& Gorski, K. The use of sexual activity measurements to assess ejaculatory performance of boars. Arch. Tierzucht. 56, 1-13 (2013).

7. Levis, D. G. \& Reicks, D. L. Assessment of sexual behavior and effect of semen collection pen design and sexual stimulation of boars on behavior and sperm output-a review. Theriogenology 63, 630-642 (2005).

8. Pound, N., Javed, M. H., Ruberto, C., Anis, S. M. \& Del Valle, A. P. Duration of sexual arousal predicts semen parameters for masturbatory ejaculates. Physiol. Behav. 76, 685-689 (2002).

9. Singh, K., Kumar, A., Honparkhe, M. \& Singh, A. K. Quantification of sexual behaviour traits in presence of teaser male in relation to Libido and semen quality in buffalo bulls. J. Anim. Res. 9(1), 143-146 (2019).

10. Hafez, E. S. E. \& Hafez, B. Reproduction in Farm Animals 7th edn, 293-397 (Lippincott Williams and Wilkins, 2013).

11. Kasimanickam, V. R., Kasimanickam, R. K., Kastelic, J. P. \& Stevenson, J. S. Associations of adiponectin and fertility estimates in Holstein bulls. Theriogenology 79, 766-777 (2013).

12. Bhakat, M. et al. Effect of age and season on semen quality parameters in Sahiwal bulls. Trop. Anim. Health Prod. 43(6), 1161-1168 (2011).

13. Fiaz, M., Usmani, R. H., Abdullah, M. \& Ahmad, T. Evaluation of semen quality of Holstein Friesian and Jersey bulls maintained under subtropical environment. Pak. Vet. J. 30(2), 75-78 (2010).

14. Koivisto, M. B., Costa, M. T. A., Perri, S. H. V. \& Vicente, W. R. R. The effect of season on semen characteristics and freezability in Bos indicus and Bos taurus bulls in the southeastern region of Brazil. Reprod. Domest. Anim. 44, 587-592 (2009).

15. Mallick, S., Aggarwal, A. \& Prakash, B. S. Seasonal changes in semen quality and correlation with plasma hormone profiles in Karan Fries bulls. Biol. Rhythm Res. 47, 967-974 (2016).

16. Rajak, S. K. et al. Testicular cell indices and peripheral blood testosterone concentrations in relation to age and semen quality in crossbred (holstein friesian×tharparkar) bulls. Asian-Australas. J. Anim. Sci. 27(11), 1554-1561 (2014).

17. Rajak, S. K. et al. Relationship of blood and seminal plasma testosterone concentrations with semen quality in crossbred bulls. Indian J. Dairy Sci. 67(2), 162-167 (2014).

18. Javed, M. T., Khan, A. \& Ali, M. Influence of season on seminal plasma testosterone and oestrogen in healthy and abnormal buffalo bulls and their relationship with other semen parameters. Vet. Arhiv. 70, 141-149 (2000).

19. Dance, A., Thundathil, J., Wilde, R., Blondin, P. \& Kastelic, J. Enhanced early-life nutrition promotes hormone production and reproductive development in Holstein bulls. J. Dairy Sci. 98, 987-998 (2015).

20. Moura, A. A. \& Erickson, B. H. Age-related changes in peripheral hormone concentrations and their relationships with testis size and number of Sertoli and germ cells in beef bulls. J. Reprod. Fert. 111, 183-190 (1997).

21. Li, X. P. et al. Supplementation with fat-coated rumen-protected glucose during the transition period enhances milk production and influences blood biochemical parameters of liver function and inflammation in dairy cows. Anim. Feed Sci. Technol. 252, 92-102 (2019).

22. Levine, R. L. et al. Determination of carbonyl content in oxidatively modified proteins. Methods Enzymol. 186, 464-478 (1991).

23. Mizera, A., Kuczaj, M. \& Szul, A. Impact of the Spirulina maxima extract addition to semen extender on bovine sperm quality. Ital. J. Anim. Sci. 18(1), 601-607 (2019).

24. Love, C. C., Garcia, M. C., Riera, F. R. \& Kenney, R. M. Evaluationn of measures taken by ultrasonography and calipers to estimate testicular volume and predict daily sperm output in the stallion. J. Reprod. Fertil. Suppl. 44, 99-105 (1991).

25. Chenoweth, P. J., Hopkins, F. M., Spitzer, J. C. \& Larsen, R. E. Guidelines for using the bull breeding soundness evaluation form. Clin. Theriogenol. 2(1), 43-50 (2010).

26. Singh, J., Kumar, A., Honparkhe, M., Dadarwal, D. \& Dhaliwal, G. S. Effect of GnRH therapy on plasma steroids, thyroid hormones and and libido in breeding bulls. Ind. Vet. J. 86, 584-585 (2009).

27. Schaefer, M., Hofmann, T., Schultz, G. \& Gudermann, T. A new prostaglandin E receptor mediates calcium influx and acrosome reaction in human spermatozoa. Proc. Natl. Acad. Sci. USA 95(6), 3008-3013 (1998). 
28. Chandras, C., Harris, T. E., Bernal, A. L., Abayasekara, D. R. \& Michael, A. E. PTGER1 and PTGER2 receptors mediate regulation of progesterone synthesis and type 111 beta474 hydroxysteroid dehydrogenase activity by prostaglandin E2 in human granulosa lutein cells. J. Endocrinol. 194(3), 595-602 (2007).

29. Aslam, M. K. et al. Identification of putative fertility markers in seminal plasma of crossbred bulls through differential proteomics. Theriogenology 82, 1254.e1-1262.e1 (2014).

30. Perumal, P. et al. Effect of season and age on scrotal circumference, testicular parameters and endocrinological profiles in mithun bulls. Theriogenology 98, 23-29 (2017).

31. Peirce, A. R. J., Downey, B. R. \& Sanford, L. M. Seasonal changes in plasma concentrations of prolactin, LH, FSH, and testosterone in young adult bulls. Anim. Reprod. Sci. 13(3), 165-176 (1987).

32. Balić, I. M., Milinković-Tur, S., Samardžija, M. \& Vince, S. Effect of age and environmental factors on semen quality, glutathione peroxidase activity and oxidative parameters in simmental bulls. Theriogenology 78, 423-431 (2012).

33. Nongbua, T. et al. Effects of season and single layer centrifugation on bull sperm quality in Thailand. Asian-Australas. J. Anim. Sci. 33(9), 1411-1420 (2020)

34. Murphy, E. M. et al. Influence of bull age, ejaculate number, and season of collection on semen production and sperm motility parameters in Holstein Friesian bulls in a commercial artificial insemination centre. J. Anim. Sci. 96, 2408-2418 (2018).

35. Žaja, ŽI. et al. Influence of different periods of the year and age on the parameters of antioxidative status and oxidative stress in the blood serum of breeding bulls. Reprod. Biol. 16, 157-164 (2016).

\section{Acknowledgements}

We would like to thank Dr Jarosław Jędraszczyk for substantive and technical support during the research. Mrs. Agnieszka Pawlak for providing the material for research and the opportunity to carry out the experiment at the insemination station.

\section{Author contributions}

We declare that all authors made substantial contributions to this manuscript. A.K. in conducting the experiment, in the conception and design of the study, and in establishing the methodology. L.H in establishing the methodology and veterinary supervision. E.G \& A.S. in the collection and assembly of data. E.C.-P. in the analysis and interpretation of results. A.K., E.G., E.C-P., A.S \& L.H in the preparation of the manuscript.

\section{Funding}

The research was partially financed by the project entitled "Science for the Husbandry-Development of methods of evaluation and selection of bulls used in semen production stations" implemented on the basis of an agreement on scientific and research cooperation with an economic entity (No. WOI.NI.4211.UW.38/ZiR).

\section{Competing interests}

The authors declare no competing interests.

\section{Additional information}

Correspondence and requests for materials should be addressed to A.K.

Reprints and permissions information is available at www.nature.com/reprints.

Publisher's note Springer Nature remains neutral with regard to jurisdictional claims in published maps and institutional affiliations.

(c) (i) Open Access This article is licensed under a Creative Commons Attribution 4.0 International cc) License, which permits use, sharing, adaptation, distribution and reproduction in any medium or format, as long as you give appropriate credit to the original author(s) and the source, provide a link to the Creative Commons licence, and indicate if changes were made. The images or other third party material in this article are included in the article's Creative Commons licence, unless indicated otherwise in a credit line to the material. If material is not included in the article's Creative Commons licence and your intended use is not permitted by statutory regulation or exceeds the permitted use, you will need to obtain permission directly from the copyright holder. To view a copy of this licence, visit http://creativecommons.org/licenses/by/4.0/.

(C) The Author(s) 2021 